\title{
Self-efficacy and Motivations among Saudi Employees toward Creating their Own Business
}

\author{
Adlah Alessa ${ }^{1}$ \\ ${ }^{1}$ Department of Business Administration, Arab East College, Kingdom of Saudi Arabia \\ Correspondence: Adlah Alessa, Department of Business Administration, Arab East College, Kingdom of Saudi \\ Arabia. E-mail: adlahalessa@yahoo.com
}

Received: March 21, 2017

Accepted: April 21, 2017

Online Published: May 17, 2017

doi:10.5539/ijbm.v12n6p75

URL: https://doi.org/10.5539/ijbm.v12n6p75

\begin{abstract}
Saudi Arabia has a unique culture and society, which has influence on the way entrepreneurship is perceived and experienced. The survey of Saudi Arabian employees suggested that men tended to have a greater interest in entrepreneurship and more often wanted to quit their job in order to start a business. Male employees also had greater levels of self-efficacy towards starting a business. The study provides new empirical and comparative evidence drawn from diverse parts of Saudi society. In so doing, the study contributes new knowledge with regards to how Saudi Arabian society, culture, policies and the economy influence attitudes, perceptions and experiences of entrepreneurship.
\end{abstract}

Keywords: self-efficacy, motivations, Saudi employees

\section{Introduction}

Saudi Arab's economy has been largely dependent on its oil reserves. The globalization in the recent times demands countries to grow dependence on sustainable economy and since the reserves are non-renewable and rapidly running out, Saudi Arabia is in need of development in the entrepreneurial sector, and thus should "foster entrepreneurship and the development of SMEs" (2008), in order to move beyond dependence on oil revenues. According to the FDI, the Middle East lagged behind in the process of globalising its economy, in respect to its pursuit of strategic growth of markets and its ability to cope with the international market (World Bank, 2003) and is currently striving hard to overcome its two main challenges; creating better jobs for an increasingly educated young workforce and pulling the economy away from traditional, labour intensive sectors like agriculture, natural resources, construction and public work.

However, the shift in the attitude towards business and entrepreneurship in Saudi Arabia is quite demanding due to cultural and social barriers. This area of study was ignored by the business researchers in the past but the inexorable globalisation has inspired researchers to perform international research, exploring cultural similarities and differences in terms of business practices and management philosophies. This has led to the study of Middle East and Arab world economies, particularly trade developments in the region (Wilson, 1995, World Bank, 2003). It is important to study the change of economies and growth of business in the Middle East, along with the contributions of these to world trade and such study requires knowledge of businesses in the Middle Eastern and Arabic states (Pfeifer and Posusney, 2003, Wilson, 2001, World Bank, 2003). As a result of these studies and literature, a general fact of the business world in Saudi Arabia came onto the surface; the negligible representation of women. For instance, the World Bank data reported that in Bahrain the workforce for women in 2000 was 36.3 per cent and by 2010 had increased to 40.6 per cent; in the United Arab Emirates the workforce was 34.5 per cent in the year 2000 and increased to 44 per cent in the year 2010. In Jordan, women representation was 13.3 for the year 2000 and it increased to 16.3 per cent in the year 2010, while in Saudi Arabia it was reported that the workforce for women in the year 2000 was 17 per cent; it only increased to reach 18.3 per cent by the year 2010. (World Bank., 2010). Moreover, Scherer et al. (1990) and Hovorka and Dietrich (2011) found that men had a higher rate of engagement in entrepreneurial activities than women in the Oman and Botswana regions. In support of these foundings, UNDP has reported that the number of women entering the workplace has increased year after year, and women have gained equality of education at all levels compare to men yet, all over the world the highest unemployment rates are among Arab women. (United Nations Development Programme UNDP, 2003,2015). Given this, The United Nations Development Program argued that 
women should be given the opportunity to enhance their countries' economic growth (United Nations Development Programme UNDP, 2003).

There are only a few studies examining Muslim male and female entrepreneurs and the relationship of religion with gender roles and ethical values. This is because the literature has very limited access to the worlds of Arab, Muslim women in particular (Essers and Benschop, 2009). Moreover, there is a dearth of studies of entrepreneurial behaviours and performances of Arab women as compared to Arab men (Dechant and Al-Lamky, 2005, El-Ghannam, 2002, Maysami and Goby, 1999, Abdalla, 1996). In the Middle East and North Africa, countries such as Saudi Arabia, United Arab Emirates and Oman form the Arab Gulf Cooperation are still under research, concerning their economic potential as well as whether special attention is needed (Ahmed, 1998). Indeed, the reason for the absence of studies focusing on female entrepreneurs in Arab countries, particularly in Muslim society, is because the economic participation of women depends on social and family control over women and the restriction of their mobility compare to their male counterparts (Syed, 2011).

Historically, Arabic culture does not prohibit women from having power and authority (Guthrie, 2013), based on the Islamic concept that women can work as much as they wish as long as the work does not interfere with their duty to family. On the contrary, men have no restrictions towards working hours (Read, 2003, Darwiche, 1999). Etemad Moghadam and Naguib (2012) found that a number of studies have examined factors such as marriage and young children in relation to women and work, concluding that these factors play significant roles in preventing women from participating in the labour market. This relationship was tested further in detail in a study where Danish and Smith (2012) interviewed 33 female entrepreneurs, based in Jeddah and found that the challenges and constraints faced by Saudi female entrepreneurs are in fact, societal and institutional. This was verified by the evidence that it might take a Saudi female an entire month to register her business, while for women in Bahrain registration takes only an hour (Fakkar, 2007, Afsaruddin, 1999). For Arab women, it is unusual to ask a lending institution to finance their start-up businesses, and they are unlikely to have access to significant amounts of capital (Naser et al., 2009). Evidence from another study of women in Arab countries stated that women rely on external resources (Hattab, 2012).

The social position of Arab women started strengthening in the late 1910s. In 1919, there was a feminist movement led by a very famous Arab woman: an Egyptian named Huda Sharawi. This movement affected the Arab countries in the 1930s and 1940s. It caused networks to be set up in Egypt, Syria, Lebanon and Iraq (Sidani, 2002) and because of the efforts of intellectuals involved in the feminist movement, fundamental social and political changes occurred in many Arab countries. The feminist movement opened the door for all Arab women to have the right to an education and to work in fields such as medicine and teaching. As the report of Arab human development stated, there have been significant improvements in women rights in the Arab world (Arab Human Development Report, 2002). Finally, over time the state of Arab women have seen a change for better, in that they have accomplished a big step toward social democracy and a place in the social economy. Noland and Pack (2011) also asserted that Middle Eastern countries have attempted to divert their economies and encourage multinational corporation (MNC) investment by giving women equal opportunities to contribute to economic growth. However, the social barriers of Saudi Arab make it difficult for business ventures to flourish with the incorporation of female workers. The priorities of married Arab women are inclined towards their home hence making it challenging to build relationships in the workplace. The same difficulty can be witnessed in an epatriate network that is mostly male-dominated (Hutchings \& Michailova, 2014). These factors hinder the incorporation of Arab women in many working fields. The Arab Human Development Report (2002) and Esnard (2016) also stated that female participation in politics and the economy is still low. The most important challenge that female entrepreneurs face is to gain economic and political empowerment (Mustapha et al., 2005). The social position of women and their responsibility to their families in the Arab world leads to their lack of economic empowerment.

However, the Arab world seems to work towards the eradication of gender bias in the working fields due to the vast economic benefits that developed countries have witnessed as a result of incorporating females in entrepreneurship. In developed countries, women own 25 per cent of total businesses and it is quicker for women to start a business than for men to do so (Woldie and Adersua, 2004). The creation of opportunities in achieving gender equality improves economic growth (Eddleston and Powell, 2008), and female entrepreneurs add diversity to their business environments in developed countries as compared to the males. Examples of this diversity can be seen in China, Asia and Africa, where women are very active in business activities (Verheul et al., 2006). As Saudi Arab is following the footsteps of such developed countries, it needs to weigh the potential of its employees, males and females, towards initiating their own businesses.

This paper presents the analysis of the survey of male and female employees in Saudi Arabia. The first focuses 
on the gender differences between male and female employees. The purposse is to assess their individual characteristics when choosing the important parameters that can be used to examine the propensity to start-up a business. For instance, demographic characteristics and self-efficacy will be addressed to see their potential toward entrepreneurial activities.

The questions that are addressed in this paper are as follows:

(1) Explore the attitudes of employees toward entrepreneurship and the perceived desirability of starting a business.

(2) Explore self-efficacy to start a new business (i.e. their entrepreneurial "self-efficacy").

(3) Examine differences in start-up intentions by gender and other demographic characteristics.

\section{Research Methodology}

\subsection{Questionnaire Design}

A quantitative survey was adopted in this paper in order to explore the potential of male and female Saudi employees. Additionally, this paper focuses on the employees' perception of whether or not they were willing, or had the opportunity, to be their own bosses. The main objective of this stage was to measure employees using the variables of the questionnaires and to measure their self-efficacy, in order to discern the attitudes of male and female employees towards entrepreneurship activities in starting-up a business.

The measurement adopted a quantitative survey that focused on the employees who did not currently own a business in Saudi Arabia, regardless of whether they had a business previously. Then, after collecting the data, the paper attempted to see what linked Saudi employees to Saudi entrepreneurs when it came to deciding to create a business, It sought to find out which gender has more self-efficacy: males or females.

Again, this stage also targeted employees in both the private and public sector to see which employees in these two groups might have an intention to start up a business. It also assessed whether an employee's career sector (private or public) influenced his or her self-confidence. Worldwide researchers have found that male entrepreneurs tend to be more active than female entrepreneurs (Wilson et al., 2007) are, although empirical factors indicate that girls have more self-efficacy than boys do in starting-up new businesses (Kickul et al., 2004). Indeed, in Brazil female entrepreneurs are more than male entrepreneurs (Teixeira, 2016). In Saudi Arabia, some sectors require that employees have attained a certain level of education, while other sectors do not have any educational requirement. This research has not focused on the education of employees; the lens has focused on both educated and uneducated people, to assess whether or not educated people have more potential to create new businesses. In addition, this paper hopes to provide an understanding of how Saudi employees how this connects to measures of Saudi self-efficacy, in order to see if employees have low or high-self-esteem (Bandura, 1995) (Bandura, 1995, 1997). It might be that Saudi employees have high self-efficacy but no attention to business creation, or that they have high attention to business creation but no self-efficacy, or perhaps both will be true. Bandura (1977) asserted that the different behaviours exhibited by different people could be affected by their sense of self-efficacy.

\subsection{Data Collection}

The type of quantitative data was about asking the employees about facts or opinions; the opinion questions could not be assumed to elicit the correct answer size, because different people would provide different answers (Easterby-smith et al., 2003). As each of the questions had 5 to 6 answers to pick from, in what is called ordinal data, participants needed to give only one answer, depending on whether they agreed or disagreed with the question (Hakim, 1987). The reasons for handing people questionnaires at different locations was to allow us to distribute as many as possible to people in locations that the we were attending, which would ensure that the questionnaires were completed and returned at the same time. This would also save a lot of time and we would have prepared enough copies and pens to provide to the participants. The first section asked Saudi employees about employees (i.e. their sex, age, and marital status). Section two had eight questions about their perception of their knowledge and self-efficacy in starting-up a business. Finally, section three was about male and female Saudi employees' attitudes toward their ambitions. Questionnaires were given by hand to participants there were no problems in terms of rejecting the filling out of the questionnaires. We targeted the malls in the morning to distribute the questionnaires, as in the morning more women go to the mall than men.

We started our journey every morning from 10:00 am to 1:00 pm. Then the next step that we followed was to go to a different mall but at 4:00 pm to 9:00 pm, as most men are attending the malls either with their wife or with their family at those times; this process took almost one and half months. Finally, in the afternoon we focused on 
the market and people in the street; however, the whole process, in order to have 410 participants, took around two months to finish.mMoreover, the main problem that we faced was that some of the participants kept asking questions so we tried to make sure the participants had understood all of the questions when participants finished filling in the questionnaires. We asked whether the questionnaire was clear enough for them or whether they did not know what answer they were supposed to pick, but those participants said things like 'we did understand all the questions but we want to make sure of some of the questions instead of picking the wrong answer to fit us.' The second section of the study was a study that could help us to avoid failure of the main research by not following specific protocols or even not implementing the adapted method or instrument (Edwin et al., 2001)._

The questionnaires was carried out among, 410 employees from both genders were selected randomly from different demographic areas of Riyadh. As this was the capital city, we tried to cover as many different locations as she could to have this number of participants in order to obtain a range of different answers from different locations with different environments. However, we kept in mind the need to have an equal distribution among the participants in order to have an overall equal distribution and to avoid bias in the analysis. The pilot was carried on in Saudi Arabia for a number of reasons. Firstly, the fact we were from the same country, as well as living in the capital city, gave us more flexibility to move around the city comfortably and to confirm the validity and reliability of the questionnaires. Secondly, it saved time and money as choosing a different city could be expensive and time-consuming because we would not know where she had to start from in conducting the questionnaires, and also she would have had limited access for sending emails to participants in different cities because of a lack of contacts. From this perspective, parts of the questionnaires were distributed by email to participants who lived in the capital city. The third factor was handing the questionnaires by hand to participants, which gave participants the freedom to ask questions while they were filling out the questionnaires. The choice of 410 participants as a sample was a consideration chosen based on going beyond the standard limit number of doing any survey, but this research sample was 410 of both males and females, which we believed to be still within the limitation and recommended angle of a pilot study. we translated the questionnaires into Arabic in order to meet the social need. However, the layout design of the questionnaires was used to avoid the participants checking the wrong answer (category).

In fact, using questionnaires and distributing them among the population was easier in some ways to manage and distribute the questions, because, as Bryman (2004) mentions, questionnaires can be filled in by the individuals and there is no need for us to be seen. Distributing the questionnaires among Saudi employees of both genders would be done randomly, since the aim of this paper was to rely on the questionnaires to obtain information about male and female employees in Saudi Arabia, particularly in Riyadh, the capital city. An important fact was that it would give the participants the chance to ask any questions if any of them did not understand certain questions from the questionnaires. The number of questions included in the questionnaires was 17 , structured in two sections. Apart from all this, all of the questions were based on the open/closed model, and some of the questions set a scale measuring the employees' view of their work value, which examined the attitude of employees toward their work and then their attitude toward starting up businesses

\section{Methodology}

The quantitative investigation was distributed in two different ways: firstly by e-mail, with a cover letter attached, giving a brief description of the research, explaining the objective of the paper in a very brief way. A deadline was provided to avoid delay in receiving the questionnaire back, and an expression of thanks to the participants for taking the opportunity and time to fill out the questionnaires was added (Kumar, 2005). The second way was by manually distributing the questionnaires in public places and in different locations in the city, such as in shopping malls, to people walking in the street, in restaurants and supermarkets, many places that would allow us to get as many responses as she could. However, the lens of this paper was to have a random sampling to pick from, excluding any entrepreneurs. In this case a stratified sample can be formed where each employee would be chosen at random with each of these strata (Easterby-smith et al., 2003). Therefore, the sample of quantitative approach was concerned with private and public sectors, and with charity sector employees. These questions were adapted from GEM and a survey of farm business activities. Descriptive statistics (means, standard deviations, number and percentages) were used to describe the quantitative and categorical study variables. One-way analysis of variance was used for continuous measures. Chi-square statistics were used for categorical data. A two-sided $\mathrm{p}$ value $<0.05$ was considered statistically significant. SPSS version 18 (SPSS Inc., Chicago, IL, USA) was used for all analyses.

\section{Result}

This paper reveals the demographic characteristics of Saudi male and female employees, starting with details on 
gender, age, marital status, educational level and qualifications. In total, 410 respondents responded to this survey, which was divided equally between males and females (50 per cent were male and 50 per cent were female). The equal number of both genders provided a fair comparison for the study. The majority of male and female employees presented in the survey belonged to the age group 25 to 34 years old. The second most common age group was 35 to 44 years old, which was almost equally represented by male and females. The minority of the respondents belonged to the age group 55 to 64 , with only 1.0 per cent of male respondents and 0.5 per cent of female respondents. Despite the differences in age ranges among male and female respondents, no significant differences were observed (chi square $2.218,3 \mathrm{df}$, and $\mathrm{p}=0.528$ ).

Table 1. Male and female ages

\begin{tabular}{lllll}
\hline Age Bands & $\begin{array}{l}\text { Male } \\
\text { n. }\end{array}$ & $\%$ & $\begin{array}{l}\text { Female } \\
\text { n. }\end{array}$ & $\%$ \\
\hline Under 25 & 24 & 11.7 & 25 & 12.2 \\
25 to 34 & 107 & 52.2 & 106 & 51.7 \\
35 to 44 & 50 & 24.4 & 58 & 28.3 \\
$>=45$ & 24 & 11.7 & 16 & 7.8 \\
Total & 205 & 100 & 205 & 100 \\
\hline
\end{tabular}

Upon evaluation of the marital status among the respondents, the single male and female employees were equally distributed (33.2 per cent and 32.7 per cent respectively). The vast majority of the respondents were married. However, more males were married than females (65.4 and 58.5 per cent respectively). Furthermore, females were more likely to be separated or widowed compared to males $(8.8$ per cent and 1.5 per cent respectively). Because of the above differences, this resulted in a significant difference among the respondents (chi square $11.493,2 \mathrm{df}$, and $\mathrm{p}=0.003$ ). Studies from different countries in the region indicate that women withdraw from work in the private sector after marriage, because it is considered incompatible with their household responsibilities. (Mcloughlin, 2013).

Along the same line, Buttner (1993) asserted that, historically, female entrepreneurs tend to be widowed, divorced or at home taking care of their children; they start-up their businesses out of financial necessity. In the case of Saudi Arabia, it is possible that the manner in which the survey was undertaken: administered in the street, shopping malls and within employee offices, may have contributed to the slightly higher proportion of separated and widowed females seen in this study. The marital status of these females led them to be more likely to work outside of the home and therefore more likely to be present within this survey.

Table: 2 Male and Female Marital Status

\begin{tabular}{lllll}
\hline Marital Status & Male & \multicolumn{2}{c}{ Female } \\
& n. & $\%$ & n. & $\%$ \\
\hline Single & 68 & 33.3 & 67 & 32.7 \\
Married & 135 & 65.4 & 120 & 58.5 \\
Separated \& Widowed & 3 & 1.5 & 18 & 8.8 \\
Total & 205 & 100 & 205 & 100 \\
\hline
\end{tabular}

\subsection{Education Levels of Male and Female Employees}

The distribution of education levels among the respondents with regards to primary school, high school, college and postgraduate studies were almost equally represented between both genders. It was expected that Saudi respondents holding a higher education level were more likely to be employed. However, there was not found to be a significant difference between genders, and females were more likely to have a bachelor's degree compared to their male counterparts (51.0 per cent and 39.5 per cent respectively). Moreover, females were less likely to have a $\mathrm{PhD}$ compared to males ( 8.3 per cent and 10.7 per cent respectively) (chi square $7.913,3 \mathrm{df}$, and $\mathrm{p}=0.059$ ). Some of the studies showed that there are no differences in the personality characteristics between male and female entrepreneurs (Buttner, 1993), but males tend to be motivated by economic reasons whereas females are motivated by families' need. Of the total valid number of respondents to this question in the study, males were more likely to be qualified in science compared to females (59.0 per cent and 45.7 per cent respectively), while 
females were more frequently qualified in the arts and humanities (such as music, art and history) compared to males (26.9 per cent and 14.4 per cent respectively). This resulted in a significant difference between males and females (chi square 12.266, $3 \mathrm{df}$, and $\mathrm{p}=007$ ). Interestingly, some research findings show that individuals with a high level of education have the potential toward entrepreneurial activities (Delmar and Davidsson, 2000), and another study, conducted in New Zealand, similarly found a high correlation between education and entrepreneurship (Frederick, and Chittock 2006).

\subsection{Employment and Skills}

It was found that most male and female employees worked full-time in their current jobs (92.7 per cent and 83.9 per cent respectively), and the rest of the respondents from both genders worked part-time ( 7.3 per cent and 16.1 per cent respectively). With regard to their sector of employment, it appeared that males and females were equally distributed with regard to the governmental sector ( 84.4 per cent and 81.5 per cent respectively); however, female employees ( 8.8 per cent) were more frequently found to work for non-governmental organizations compared to male employees ( 3.9 per cent). This resulted in insignificant differences between the genders (chi square 4.316, 2df, and $\mathrm{p}=0.116$ ). Out of the 410 participants, no males recorded that they worked for the charity sector. In comparison, females responded that they did work in this sector, although the number was very low (1.5 per cent). It appears that male and female employees were equally distributed with regard to having been in employment for more than six years (39.5 per cent and 42.0 per cent, respectively). For employment between four and six years, there were more males ( 22.9 per cent) than females and for employment between one and three years there were still more males ( 26.3 per cent) than females ( 21.5 per cent). Moreover, females were more frequently found to have worked for less than one year, compared to males (20.0 per cent and 11.2 per cent respectively), (chi square $8.319,3 \mathrm{df}$, and $\mathrm{p}=0.40$ ). The questionnaire used six questions that asked respondents to identify if they believed they were capable of starting a new business. These six questions were adapted from GEM and a survey of farm business activities.

\subsection{Attitudes towards Starting a Business}

The results showed that 89.8 per cent of the female respondents answered that they had never owned or managed a business compared to males ( 71.2 per cent). Males were also shown as more dominant in owning and managing their own business ( 28.8 per cent) compare to females (10. 2 per cent). In fact, it was noted that this test produced a significant difference between males and females (chi square 22.426 , $1 \mathrm{df}$, and $\mathrm{p}<0.0001$ ). It showed that the percentage of male employees who considered starting a business was 55.6 per cent. Another perspective belongs to females, who were not interested in running or having their own business (46.3 per cent). Thus, the results showed significant differences, with males more strongly interested in starting a business (chi square $13.012,2 \mathrm{df}$, and $\mathrm{p}<0.0001)$.

\subsection{Motivations}

The reasons behind starting up a business vary widely (Birley and Westhead, 1994). For some the sense of autonomy that is derived from being their own boss is an important motivator (Stanworth et al., 1989). One of the leading business Olayan (2015) the connection of the family played a role in a MENA woman's obtaining a career. However, women can start their business if they want and use presumably their previous success (Arabianbusiness.com, 2015).

Accordingly, over 33 per cent of female respondents reported that becoming their own boss ( $n=66,32.2$ per cent) was an important motivation, stated as "Influence A lot", while the percentage of males who agreed with this was less ( $\mathrm{n}=52,25.4$ per cent). 31.7 per cent of males stated that this factor constituted "a fair amount of influence" but only 20 per cent for females did so; these two percentages indicated that the relationship was not significant (chi square 10.434, $4 \mathrm{df}$, and $\mathrm{p}=0.034$ ). Supporting the findings of Tyszka et al., (2011) other reasons to start up a business were wealth, need of independency, achievement, personal development, autonomy, market opportunities, being disappointed in a career (Birley and Westhead, 1994) self-realization (Cassar, 2007), opportunities, welfare, achievement (Kolvereid, 1992) and to escape from the labour market (Goffee and Scase, 1985). Furthermore, Wärneryd, (1988) asserted that family are not considered as a priority for entrepreneurs. Interestingly, the response to choose when and what hours employees can work showed remarkably similar answers among males and female. Female in Palestine own relatively small size of business three to ten employees. Besides that their culture, access to finance and lack of support services consider the main constraints and challenges female entrepreneurs face in Palestine. Moreover, female in Palestine are driven by opportunity rather than necessity into business and their perceptions towards entrepreneurship as a career (Sultan, 2016). Choosing what hours you can work had no influence on 22.0 per cent of females at all, compared to 21.5 per cent of males. However, 27.3 per cent of females were influenced a lot by choosing what hours you can work, 
as were 30.2 per cent of their male counterparts. This relationship was not found to be significant (chi square 0.796, 4df, and $\mathrm{p}=0.93$ ). Banerjee and Newman (1993) argue that the occupational choice of the individuals can enhance the growth of the economy and its development. As suggested by Monsen et al. (2012), to make differences in the economy individuals have to switch from paid employment to self-employment. In terms of combining caring responsibilities with work, males reported having a fair amount of influence in this category (29.3 per cent), while females reported that they did not know or that this was not applicable (12.7 per cent), this was also found to be not significant (chi square 5.047, 4df, and $\mathrm{p}=0.283$ ). Ractitioners and policymakers need to be aware that marketing self-efficacy can be an important driver of new firm creation. (Antoncic et al. 2016).

Some employees like to have their own business in order to escape from a large company. 29.3 per cent of male employees $(n=60)$ reported that this factor had a little influence on them and 19.0 per cent $(n=39)$ of females agreed with this. An additional variable for males and females, however, showed that 24.9 per cent $(n=51)$ of males said they were influenced a fair amount by this variable while 14.6 per cent $(n=30)$ of females said that they did not know or that it was not applicable. With a different category from the same question, males $(\mathrm{n}=59$, 28.8 per cent) considered working with friends or family as having only "a little influence" compared to females. The same percentage was found for both males and females, with 21.5 per cent of males responding with "a fair amount of influence" and the same percentage of females responding with "influenced a lot". 26.3 per cent of males claimed that they were not influenced at all by working with family or friends, compared to 30.7 per cent of females. Furthermore, there were close results between male and females, who did not know or who said this was "not applicable" (11.2 and 10.2 per cent respectively) and this produced a significant result (chi square 12.747 , 4df, and $\mathrm{p}=0.013$ ).

Almost half of the total sample, and more than half of the employees from both genders, indicated the same reasons for creating personal financial security, which considered influence important ( $\mathrm{n}=85,41.5$ per cent for both genders). Males also thought it had "a lot of influence" (41.5 per cent) and 8.8 per cent of females did not know or felt it was not applicable to them, which showed that there was no significant relationship for either gender (chi square 7.913, 4df, and $\mathrm{p}=0.095$ ). According to this perspective, males and females were almost equal in their views about the family tradition of self-employment and a "fair amount of influence" was perceived in male participants ( $\mathrm{n}=49,23.9$ per cent). Another significant difference was drawn from female respondents who felt that they "did not know" or that it was not applicable to them (16.1 per cent) (chi square 9.815, df4, and $\mathrm{p}=0.044)$. In terms of the strength of business ideas, females were more likely to be "not influenced at all" (17.6 per cent) compared to their male counterparts (10.7 per cent). With regards to "a little influence", "a fair amount of influence", "a lot of influence", or "do not know", males' and females' responses were equal (chi square 5.171, $\mathrm{df4}$, and $\mathrm{p}=270$ ). With regards, to dissatisfaction with their career it illustrates that "no influence" is a more common perception in females (39.0 per cent) compared to males. Also, "a little influence" accounted for 27.8 per cent of the male respondents compared to 14.6 per cent for females. However, "a lot of influence" was more commonly indicated in female respondents (14.1 per cent) compared to males ( 9.8 per cent); this resulted in a significant difference between the genders (chi square 15.129, 4df, and $\mathrm{p}=0.004$ ).

Table 3. Motivations of employees

\begin{tabular}{|c|c|c|c|c|c|c|c|c|c|c|c|c|c|}
\hline \multirow[t]{2}{*}{ Motivation statements } & \multirow[t]{2}{*}{ Gender } & \multicolumn{2}{|c|}{$\begin{array}{l}\text { Not } \\
\text { Influenced at } \\
\text { all }\end{array}$} & \multicolumn{2}{|c|}{$\begin{array}{l}\text { A little } \\
\text { Influence }\end{array}$} & \multicolumn{2}{|c|}{$\begin{array}{l}\text { A fair amount } \\
\text { of Influence }\end{array}$} & \multicolumn{2}{|c|}{$\begin{array}{l}\text { Influence A } \\
\text { lot }\end{array}$} & \multicolumn{2}{|c|}{$\begin{array}{l}\text { Do not Know or } \\
\text { not Applicable }\end{array}$} & \multicolumn{2}{|c|}{ Total } \\
\hline & & & & $\mathrm{n}$. & $\%$ & $\mathrm{n}$. & $\%$ & n. & $\%$ & $\mathrm{n}$. & $\%$ & n. & $\%$ \\
\hline To become your own & Male & 27 & 13.2 & 41 & 20.0 & 65 & 31.7 & 52 & 25.4 & 20 & 9.8 & 205 & 100 \\
\hline $\begin{array}{l}\text { boss and be } \\
\text { independent }\end{array}$ & Female & 35 & 17.1 & 34 & 16.6 & 41 & 20.0 & 66 & 32.2 & 29 & 14.1 & 205 & 100 \\
\hline To choose when and & Male & 44 & 21.5 & 41 & 20.0 & 48 & 23.4 & 62 & 30.2 & 10 & 4.9 & 205 & 100 \\
\hline $\begin{array}{l}\text { what hours you can } \\
\text { work }\end{array}$ & Female & 45 & 22.0 & 39 & 19.0 & 53 & 25.9 & 56 & 27.3 & 12 & 5.9 & 205 & 100 \\
\hline To combine caring & Male & 28 & 13.7 & 51 & 24.9 & 60 & 29.3 & 50 & 24.4 & 16 & 7.8 & 205 & 100 \\
\hline $\begin{array}{l}\text { responsibilities with } \\
\text { work }\end{array}$ & Female & 32 & 15.6 & 40 & 19.5 & 51 & 24.9 & 56 & 27.3 & 26 & 12.7 & 205 & 100 \\
\hline To escape from a large & Male & 50 & 24.4 & 60 & 29.3 & 51 & 24.9 & 31 & 15.1 & 13 & 6.3 & 205 & 100 \\
\hline company & Female & 56 & 27.3 & 39 & 19.0 & 41 & 20.0 & 39 & 19.0 & 30 & 14.6 & 205 & 100 \\
\hline To work & Male & 54 & 26.3 & 59 & 28.8 & 44 & 21.5 & 25 & 12.2 & 23 & $11.2 *$ & 205 & 100 \\
\hline
\end{tabular}




\begin{tabular}{|c|c|c|c|c|c|c|c|c|c|c|c|c|c|}
\hline friends/families & Female & 63 & 30.7 & 34 & 16.6 & 43 & 21.0 & 44 & 21.5 & 21 & $10.2 *$ & 205 & 100 \\
\hline To create personal & Male & 11 & 5.4 & 30 & 14.6 & 53 & 25.9 & 85 & 41.5 & 26 & 12.7 & 205 & 100 \\
\hline financial security & Female & 26 & 12.7 & 29 & 14.1 & 47 & 22.9 & 85 & 41.5 & 18 & 8.8 & 205 & 100 \\
\hline Family tradition of & Male & 74 & 36.1 & 46 & 22.4 & 49 & 23.9 & 17 & 8.3 & 19 & 9.3 & 205 & 100 \\
\hline self-employment & Female & 75 & 36.6 & 45 & 22.0 & 29 & 14.1 & 23 & 11.2 & 33 & $16.1 *$ & 205 & 100 \\
\hline The strength of the & Male & 22 & 10.7 & 38 & 18.5 & 69 & 33.7 & 59 & 28.8 & 17 & 8.3 & 205 & 100 \\
\hline business idea & Female & 36 & 17.6 & 38 & 18.5 & 60 & 60 & 29.3 & 50 & 24.4 & 21 & 205 & 100 \\
\hline Dissatisfaction with & Male & 55 & 26.8 & 57 & 27.8 & 56 & 27.3 & 20 & 9.8 & 17 & 8.3 & 205 & 100 \\
\hline your career & Female & 80 & 39.0 & 30 & 14.6 & 49 & 23.9 & 29 & $14.1 *$ & 17 & 8.3 & 205 & 100 \\
\hline
\end{tabular}

$* \mathrm{P}=<0.05$

\subsection{Self-Efficacy}

One of the main objectives of this survey was to explore the self-efficacy of employees toward their interest in being their own boss. In order to do this, general self-efficacy questionnaires were adapted for use in this paper. Questions were drawn from studies that included self-efficacy, ability (adopted from Ralf Schwarzer).The first questions reported below used Likert scales to measure attitudinal data about their perceived abilities (convincement about their abilities to undertake a task), on scales that ranged from: 1: "not at all convinced", 2: "quite convinced", 3: "almost convinced", 4: "very convinced", 5: "extremely convinced".One of the results suggest that it is not the objective ability that motivates individuals but it is self-efficacy (Markman et al., 2003). In contrast, a different finding by Tyszka et al., (2011) argues that the most significant quality for individuals to possess as an entrepreneur is motivation. Another important observation with regard to their ability to solve problems was that females reported that this was "almost true" more often than males ( 40.0 per cent and 33.2 per cent respectively). However, males indicated "extremely true" with regards to solving problems more frequently than females ( 25.9 per cent and 18.5 per cent respectively) although no significant results were found (chi square 6.782, 4df, and $\mathrm{p}>0.148$ ). However, employees have lower levels of self-efficacy compared to entrepreneurs (Tyszka et al., 2011).

Additional differences in the respondents' opinions were noted between male and female employees. It can be noted from that the male and female respondents indicated "almost capable" with regards to being able to solve a problem, with 33.2 and 40.0 per cent respectively. Also 27.8 per cent of males indicated "extremely capable" compared to females' 12.7 per cent. This yielded very significant differences between Saudi male and female employees (chi square 19.689, $4 \mathrm{df}$, and $\mathrm{p}<0.0001$ ). These results appear to support the view that self-efficacy is based on attainment and past experience (Bandura, 2006). A different category in the same part of the question indicated that males were also "extremely capable" ( 28.3 per cent), and females indicated that they were "almost capable" in managing money ( 30.2 per cent) more frequently than males. However, males indicated that they were "extremely capable" more frequently compared to females (chi square 16.587, $4 \mathrm{df}$, and $\mathrm{p}=0.002$ ). No significant differences between the genders were found with regards to their response in being creative (chi square $9.397,4 \mathrm{df}$, and $\mathrm{p}=0.052$ decision). Females were "quite capable" in getting people to agree with them more often than males (22.9 per cent and 16.1 per cent respectively). However, males were more often "extremely capable" ( 24.9 per cent) compared to females ( 13.7 per cent) (chi square 10.008 , $4 \mathrm{df}$, and $\mathrm{p}=0.04$ ). Again, no significant difference was observed between males and females with regard to being a leader and their responses were almost equally distributed, although males were more frequently found to indicate that they had extreme capabilities with regard to being a leader compared to females $(28.3$ per cent and 16.6 per cent respectively). Despite the above difference, no significant differences were found (chi square 9.016, 4df, and $\mathrm{p}=0.060$ ). A significant difference with regard to the responses between males and females was observed in responses to making a decision; females were "almost capable" more frequently (36.6 per cent) compared to males (26.3 per cent). Males, however, indicated that they were "extremely capable" more frequently (35 per cent) compared to females (17.1 per cent). This resulted in significant difference between the genders (chi square 15.545 , 4df, and $\mathrm{p}=0.004)$.

Table: 4 Self-efficacies

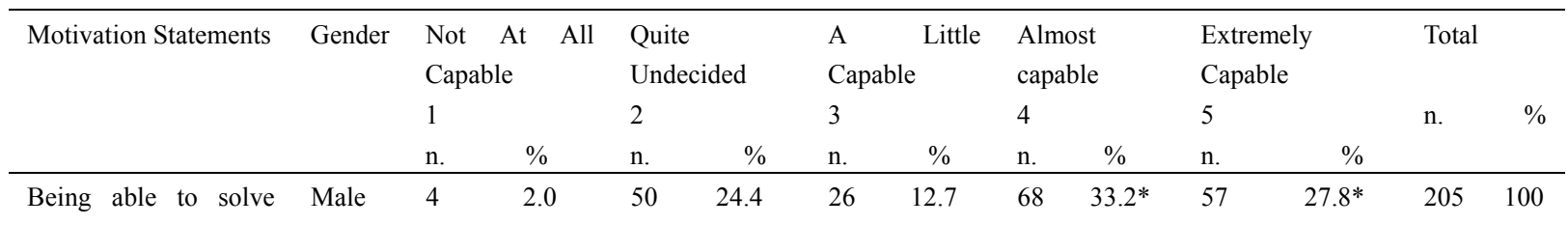




\begin{tabular}{|c|c|c|c|c|c|c|c|c|c|c|c|c|c|}
\hline problems & Female & 4 & 2.0 & 45 & 22.0 & 48 & 23.4 & 82 & $40.0^{*}$ & 26 & $12.7 *$ & 205 & 100 \\
\hline \multirow[t]{2}{*}{ Managing money } & Male & 12 & 5.9 & 31 & 15.1 & 51 & 25.4 & 52 & 25.4 & 58 & 28.3 & 205 & 100 \\
\hline & Female & 16 & 7.8 & 40 & 19.5 & 62 & 30.2 & 62 & 30.2 & 25 & 12.2 & 205 & 100 \\
\hline \multirow[t]{2}{*}{ Being creative } & Male & 2 & 1.0 & 36 & 17.6 & 50 & 24.4 & 64 & 31.2 & 53 & 25.9 & 205 & 100 \\
\hline & Female & 5 & 2.4 & 38 & 18.5 & 63 & 30.7 & 69 & 33.7 & 30 & 14.6 & 205 & 100 \\
\hline \multirow{2}{*}{$\begin{array}{l}\text { Getting people } \\
\text { agree with you }\end{array}$} & Male & 5 & 2.4 & 33 & 16.1 & 50 & 24.4 & 66 & 32.2 & 51 & 24.9 & 205 & 100 \\
\hline & Female & 4 & 2.0 & 47 & 22.9 & 59 & 28.8 & 67 & 32.7 & 28 & 13.7 & 205 & 100 \\
\hline \multirow[t]{2}{*}{ Being a leader } & Male & 3 & 1.5 & 37 & 18.0 & 49 & 23.9 & 58 & 28.3 & 58 & 28.3 & 205 & 100 \\
\hline & Female & 6 & 2.9 & 43 & 21.0 & 51 & 24.9 & 71 & 34.6 & 34 & 16.6 & 205 & 100 \\
\hline \multirow[t]{2}{*}{ Making decisions } & Male & 1 & 0.5 & 40 & 19.4 & 46 & 22.4 & 54 & $26.3 *$ & 64 & $35^{*}$ & 205 & 100 \\
\hline & Female & 6 & 2.9 & 42 & 20.5 & 47 & 22.4 & 75 & $36.6^{*}$ & 31.2 & 17.1 & 205 & 100 \\
\hline
\end{tabular}

$* \mathrm{P}<0.05$.

With regards to managing difficult problems, females responded more frequently that this was true, compared to males (39.0 per cent and 23.9 per cent respectively). However, males responded with the highest rated variable out of the five variables that the question contained and indicated more frequently to the items "almost true" and "exactly true" compared to females ( 37.6 per cent and 23.8 per cent respectively). A similar finding was noted for males with regards to "extremely true", compared to females ( 23.8 per cent and 22.9 per cent respectively). This resulted in a significant difference between the genders (chi square 11.476, df4, and $\mathrm{p}=0.022$ ). The participants were asked if they had attempted to find several solutions. Females responded more frequently to the "moderately true" option compared to males (35.6 per cent and 26.3 per cent respectively). Males responded more frequently to "extremely true" (34.1 per cent) compared to females ( 22.0 per cent). However, despite the above difference, no significant difference was found (chi square 9.350, df4, and $\mathrm{p}=0.053$ ). In terms of employees 'handling whatever comes their way', it was found that 42.0 per cent of females responded that this was "moderately true", compared to 24.9 per cent of males, while 22.9 per cent of males responded to "handling whatever comes their way' as "extremely true" compared to 15.1 per cent of females.

\subsection{Gender Differences and Self-efficacy}

This part discusses the five items that were intended to compare the mean of both males and females with other categories that were randomly assigned to gender, and to investigate the relationship between genders according to demographic characteristics. To starting one's own business: "What appeals to you about starting your own business", and are about self-efficacy: "If I make plans, I am convinced I will succeed in executing them", "I am confident that I can perform effectively in many different tasks", "Do you think you are .....", "I can always manage to solve difficult problems if I try hard", "When I am confronted with a problem, I can usually find several solutions", "I can usually handle whatever comes my way", "I avoid facing difficulties" and "When I have something unpleasant to do, I stick to it until I finish it". The grouping is made on the basis of emerging themes in order to help with ordering the data analysis to avoid chaotic results.

One-way ANOVA was performed on males and females individually to explore whether there were any significant differences between the variables with the sum of the selected items. These variables are the effect of age, marital status, degree and qualifications and how this related to gender differences

With regard to the items of starting a business and self-perception, insignificant $p$-values were noted for both males and females. It showed no significant effect for employees' in starting up a business ( $p=0.46$ for males and $\mathrm{p}=0.57$ for females). These results appear to refute the findings of Buttner (1993) who found that females tend to start up a business due to being unsatisfied with their slow career.

\section{Discussion}

This analysis of Saudi employees' attitudes towards entrepreneurial activities was divided into three sections to give a clear set of results. The first section focused on descriptive statistics of males and females in order to determine the differences between genders. The results showed that more of the males tended to be married, and that the females were more likely to be separated or widowed. Also, the females were more likely to hold bachelor degrees than the males. Prior studies show that in a rich country, at a higher educational level, training has positive effects on starting up a business (Blanchflower, 2004). The results of this study also suggest that more males than females worked full-time and more males worked in the governmental sectors.

In the second section of the analysis, the sum of selected questions was grouped together in order to find the difference between selected items among Saudi employees. The effects of age in starting to own business and 
self-efficacy were not significant for both genders. Bandura (1997) defined self-efficacy as the belief of individuals and their capability in accomplishing tasks or jobs, and obtaining different outcomes (Bandura, 1982) . Moreover, self-efficacy typically correlates with risk taking and opportunity (Krueger and Dickson, 1994) and career choice (Bandura, 1986). Moreover, the effect of marital status and levels of starting one's own business, developing and having a positive self-efficacy were generally not significant. Initially, gender, age, religion, and the labour market are important factors that affect the decision of individuals to be entrepreneurs (Reynolds et al., 1994, Storey, 1994) and the entrepreneurial behaviour and intention is found to play a role (Minniti and Nardone, 2007, Levesque and Minniti, 2006, Cooper and Park, 2008). The effects of self-efficacy were not usually significant. Kolvereid (1996) argues that entrepreneurial intention can be influenced by self-efficacy. In this paper, it was noted that the qualification obtained by males had a significant effect on self-perception. It seems that individuals with higher entrepreneurial intention tended to have higher self-efficacy (Chen et al., 1998, De Noble et al., 1999, Krueger et al., 2000, Scott and Twomey, 1988, Wang et al., 2002). Bearing that in mind, Langowitz and Minniti (2007) reported that females perceive themselves as less favourable as entrepreneurs compared to their counterparts.

The results imply that female employees are less confident, have low self perception and are not inclined towards owning a business. However, this can be explained on the terms of less experience as most of the female employees worked for the firm for less than one year. As self effacy is closey linked with experience and confidence in one's self perception, it validates the lack of interest of female employees in entrepreneurship. In addition to that, the social barriers also appear to be apparent in the results as most of the female employees were divorced or seperated, implying that married women in Saudi Arab are encouraged not to jeoperdarize their duty to their families for their careers. Hence the hesitation of female employees towards entreprenuership lies due to the socio-political scenario of Saudi Arab. However, female employees who were inclined towards entrepreneurship found "being their own boss" as a solid motivator as well as found the factor of working with family and friends as an important reason to shift to their own business. This correlates to the societal and institutional hindrances that women face in Saudi Arab, especially in terms of raising finance for their business initiatives. Hence they depend on the support of family to start a business venture.

\section{Conclusion}

A quantitative survey was adopted in this paper among Saudi employees. In total, 410 respondents responded to this survey. The results showed that 89.8 per cent of the female respondents answered that they had never owned or managed a business compared to males (71.2 per cent). Males were also shown as more dominant in owning and managing their own business ( 28.8 per cent) compare to females (10. 2 per cent). In addition, men tended to have greater interest in entrepreneurship and more often wanted to quit their job on order to start a business. Moreover, male employees also had greater level of self-efficacy with regards to the variables (being able to solve problems and making decisions) toward stating a business. Further study could examine the potential of male and female from other cities in Saudi Arabia toward being their own bosses and compare it with other cities.

\section{References}

Abdalla, I. (1996). Attitudes Towards Women in the Arabian Gulf Region. Women in Management Review, 11, 29-39. http://dx.doi.org/10.1108/09649429610109271

Afsaruddin, A. (1999). Introduction: The Hermeneutics of Gendered Space and Discourse in Hermeneutics and Honor. Cambridge, MA, Harvard University Press. http://www.karamah.org/wp-content/uploads/2011/10/AfsaruddinGenderedSpace.pdf

Ahmad, S. Z. (2011). Businesswomen in the Kingdom of Saudi Arabia: Characteristic, Growth Patterns and Progression in a Regional Context. Equality, Diversity and Inclusion: An International Journal, 30, 610-614. http://dx.doi.org/10.1108/02610151111167052

Ahmad, S. Z. (2011). Evidence of the Characteristics of Women Entrepreneurs in the Kingdom of Saudi Arabia: An Empirical Investigation. International Journal of Gender and Entrepreneurship, 3, 123-143. http://dx.doi.org/10.1108/17566261111140206

Arabianbusiness.com. (2015). 100 most powerful Arab women 2013. Retrieved from: http://www.arabianbusiness.com/100-most-powerful-arab-women-2013-491497.html?page=2

Bandura, A. (1977). Self-efficacy: Toward A unifying Theory of Behavioral Change. Psychological Review, 84, 191-215. http://dx.doi.org/10.1037/0033-295X.84.2.191

Bandura, A. (1986). Social foundations of thought and action: A social cognitive theory. 
https://www.uky.edu/ eushe2/Bandura/BanduraPubs.html

Bandura, A. (1991). Self-efficacy mechanism in physiological activation and health-promoting behavior. In J. Madden, IV (Ed.), Neurobiology of learning, emotion and affect (pp. 229-270). New York: Raven. https://www.uky.edu/ eushe2/Bandura/BanduraPubs.html

Bandura, A. (1995). Self-efficacy in Changing Societies. Cambridge University Press. http://dx.doi.org/10.1017/CBO9780511527692

Bandura, A. (1997). Self-efficacy: The Exercise of Control. New York, Freeman. http://dx.doi.org/10.1017/CBO9780511527692

Bandura, A. (2006). Guide for constructing self-efficacy scales. In F. Pajares \& T. Urdan (Eds.). Self-efficacy beliefs of adolescents (Vol. 5, pp. 307-337). https://www.uky.edu/ eushe2/Bandura/BanduraGuide2006.pdf

Banerjee, A. V., \& Andrew F. N. (1993). Occupational Choice and the Process of Development. Journal of Political Economy, 101(2), 274-298. http://doi.org/10.1086/261876

Birley, S. J., \& Westhead, P. (1994). A taxonomy of Business Start-up Reasons and their Impact on Firm Growth and Size. Journal of Business Venturing, 9, 7-31. https://doi.org/10.1016/0883-9026(94)90024-8

Blanchflower, D. G. (2004). Self-Employment: More May Not Be Better. National Bureau of Economic Research. http://doi.org/10.3386/w10286

Bryman, A. (2004). Social Research Methods, Oxford, Oxfored University Press.

Buttner, E. H. (1993). Female Entrepreneurs: How Far Have They Come? Business Horizons, 36, 59-66. https://doi.org/10.1016/S0007-6813(05)80039-4

Cassar, G. (2004). The Financing of Business Start-ups. Journal of Business Venturing, 19, 261-283. http://doi.org/10.1016/S0883-9026(03)00029-6

Chen, C., Greene, P., \& Crick, A. (1998). Does Entrepreneurial Self-efficacy Distinguish Entrepreneurs from Managers. Journal of Business Venturing, 13, 295-316. http://doi.org/10.1016/S0883-9026(97)00029-3

Cooper, S. Y., \& Park, J. S. (2008). The Impact of Incubator Organizations on Opportunity Recognition and Technology Innovation in New, Entrepreneurial High-Technology Ventures. Journal Of International Small Business, 26, 27-56. http://journals.sagepub.com/doi/abs/10.1177/0266242607084658

Danish, A. Y., \& Smith, H. L. (2012). Female Entrepreneurship in Saudi Arabia: Opportunities and Challenges. International Journal of Gender and Entrepreneurship, 4, 216-235. http://dx.doi.org/10.1108/17566261211264136

Darwiche, N. (1999). Women in Arab NGOs, The Arab Network for Non-governmental Organizations. Cairo.

De Noble, A. F., Jung, D., \& Ehrlich, S. B. (1999). Entrepreneurial Self-efficacy: The Development of a Measure and its Relationship to Entrepreneurial Action. Frontiers of entrepreneurship research, 73-87. http://search.proquest.com/openview/f0dd483347123c479359d3515abe1 eff/1?pq-origsite $=$ gscholar\&cbl=2 5945

Dechant, K., \& Al-Lamky, A. (2005). Towards an Understanding of Arab Women Entrepreneurs in Bahrain and $\begin{array}{lllll}\text { Oman Journal of Development } & \text { Entrepreneurship, } & 10, & \text { 123-40. }\end{array}$ http://dx.doi.org/10.1142/S1084946705000100

Delmar, F., \& Davidsson, P. (2000). Where do they come from?: Prevalence and Characteristics of Nascent $\begin{array}{llllll}\text { Entrepreneurs. Entrepreneurship \& Regional Development, } & 12, & 1-23 .\end{array}$ http://dx.doi.org/10.1080/089856200283063

EASTERBY-SMITH, M., THORPE, R. \& LOWE, A. 2003. Management Research: An Introduction, London, Sage.

Eddleston, K. \& Powell, G. (2008). The Role of Gender Identity in Explaining Sex differences in Business Owners Career Satisfier Preferences. Journal of Business Venturing, 23, 244-56. http://doi.org/10.1016/j.jbusvent.2006.11.002

Edwin, R., Van, T., \& Vanora, H. (2001). Social Research Update. Sociology at Surrey.

Eleanor, D., \& Marsha, P. (2003). Women and Globalization in the Arab Middle East: Gender, Economy, and Society. Lynne Rienner

El-Ghannam, A. R. (2002). Analytical Study of Women's Participation in Economic Activities in Arab Societies. 
Equal Opportunities International, 21, 1-18. http://dx.doi.org/10.1108/02610150210787037

Essers, C., \& Benschop, Y. (2009). Muslim Businesswomen Doing Boundary Work:The Negotiation of Islam, Gender and Ethnicity within Entrepreneurial Contexts. Human Relations, 62(3), 403-423. http://journals.sagepub.com/doi/abs/10.1177/0018726708101042

Etemad, M. F., \& Rabia, N. (2012). "Women and Work in Dubai City: An Exploration in Institutional Barriers and Potentials. Paper prepared for GERPA.

Fakkar, G. (2007). Removing Obstacles to Women's Business. Arab News.

Frederick, H. (2006). Global Entrepreneurship Monitor Aotearoa New Zealand 2005. In Series, U. S. O. M. E. R. R. (Ed.), Auckland: Unitec New Zealand. http://hdl.handle.net/10536/DRO/DU:30030701

Goffee, R. \& Scase, R. (1985). Women in Charge: The Experience of Female Entrepreneurs. London, Macmillan.

Guthrie, S. (2013). Arab Women in the Middle Ages: Private Lives and Public Roles. London, Sage.

Hakim, C. (1987). Research Design: Strategies and Choices in the Design of Social Research. London, Routledge.

Hattab, H. W. (2012). Towards Understanding Women Entrepreneurship in Middle East, North Africa Countries. Education, Business and Society: Contemporary Middle Eastern Issues, 5, 3-3. http://dx.doi.org/10.1108/17537981211265561

Hofstede, G. (1980). Culture's Consequences: International Differences in Work Related Values. Beverly Hills, CA, Sage

Hovorka, A., \& Dietrich, D. (2011). Entrepreneurship as a gendered process. International Journal of Entrepreneurship and Innovation, 12(1), 55-65.

Hutchings, K., \& Michailova, S. (Eds.). (2014). Research Handbook on Women in International Management. Edward Elgar Publishing.

Kolvereid, L. (1996). Organizational Employment Versus Self employment: Reasons for Career Intentions. Entrepreneurship Theory and Practice, 20, 23-31.

Krueger, J. N., \& Dickson, P. R. (1994). How believing in ourselves increases risk taking: Perceived selfefficacy and opportunity recognition. Decision Sciences, 25, 385-400. http://dx.doi.org/10.1111/j.1540-5915.1994.tb00810.x

Krueger, N. F., Reilly, M. D., \& Carsrud, A. L. (2000). Entrepreneurial Intentions: A competing Models Approach. Journal of Business Venturing, 15, 411-432. http://doi.org/10.1016/S0883-9026(98)00033-0

Levesque, M., \& Minniti, M. (2006). The Effect of Aging on Entrepreneurial Behavior. Journal of Business Venturing, 21, 177-194. http://doi.org/10.1016/j.jbusvent.2005.04.003

Markman, G. D., Balkin, D. B., \& Baron, R. A. (2003). Inventors and New Venture Formation: the Effects of General Self - Efficacy and Regretful Thinking. Entrepreneurship theory and practice, 27, 149-165. http://dx.doi.org/10.1111/1540-8520.00004

Maysami, R. C., \& Goby, V. P. (1999). Female Business Owners in Singapore and Elsewhere: A review of Studies. Journal of Small Business Management, 37, 96.

McGee, J. E., Peterson, M., Mueller, S. L., \& Sequeira, J. M. (2009). Entrepreneurial Self-Efficacy: Refining the Measure. Entrepreneurship Theory and Practice, 33, 965-988. http://dx.doi.org/10.1111/j.1540-6520.2009.00304.x

Minniti, M., \& Nardone, C. (2007). Being in Someone Else's Shoes: The Role of Gender in Nascent Entrepreneurship. Small Business Economics, 28, 223-238. doi:10.1007/s11187-006-9017-y

Mustapha, K., Nabli, C., Nadereh, C., Leora, K., Marjan, E., Talajeh, L., Silvia, M., Seemeen, S., Federica, S. \& Neda, S. (2005). The Environment for Women's Entrepreneurship in the Middle East and North Africa Region. http://siteresources.worldbank.org/INTMENA/Resources/Environment_for_Womens_Entrepreneurship_in_ MNA_final.pdf

Naser, K., Mohammed, W.R. \& Nuseibeh, R. (2009). Factors that Affect Women Entreprenurs: Evidence From an Emerging Economy. Internatinal Journal of Organizatinal Analysis, 17, 225-247. 
http://dx.doi.org/10.1108/19348830910974932

Noland, M. Pack, H. (2011). The Arab Economies in a Changing World, Second Edition. Peterson Institute for International Economics.

Oman-Spacing. (2010). Alasdair Drysdale. International Middle East Study Journal, 42, 123-144.

Prathyusha, P., \& Ramesh, D. (2015). Women Entrepreneurship: Issues and Problems Advances in Economics and Business Management (AEBM), 2(7), 726-728.

Read, J. G. (2003). The Sources of Gender Role Attitudes Among Christian and Muslim Arab American Women. Sociology of Religion, 64, 207-33. https://doi.org/10.2307/3712371

Reynolds, P., Storey, D. J., \& Westhead, P. (1994). Cross National Comparisons of the Variation in New Firm Formation Rates. Regional Studies, 28, 443-456. http://dx.doi.org/10.1080/00343409412331348386

Scherer, R., Brodzinski, J. \& Wiebe, F. (1990). Entrepreneurial Career Selection and Gender: A socialization Approach. Journal of Small Business Management, 28, 37.

Scott, M. G., \& Twomey, D. F. (1988). The Long Term Supply of Entrepreneurs: Students Career Aspirations in Relation to Entrepreneurship. Journal of Small Business Management, 26, 5-13.

Segal, G., Borgia, D. \& Schoenfeld, J. (2002). Using Social Cognitive Career Theory to Predict Self-employment Goals. New England Journal of Entrepreneurship, 5, 47-56.

Sidani, Y. (2002). Management in Lebanon. In WARNER, M. (Ed.), International Encyclopedia of Business and Management (2nd ed.). London: Thomson Learning.

Stanworth, J., Stanworth, C., Granger, B., \& Blyth, S. (1989). Who Becomes an Entrepreneur? International Small Business Journal, 8, 11-22.

Statisitics, N. (2012). Marriages in England and Wales, 2010.

Storey, D. J. (1994). Understanding the Small Business Sector. London, Routledge.

Suhail, S. (2016). Women entrepreneurship working in a conflict region: the case of Palestine. https://doi.org/10.1504/WREMSD.2016.074970

Syed, Z. A. (2011). Evidence of the Characteristics of Women Entrepreneurs in the Kingdom of Saudi Arabia. Gender and Entrepreneurship, 3, 123-143. http://dx.doi.org/10.1108/17566261111140206

Tyszka, T., Cieślik, J., Domurat, A., \& Macko, A. (2011). Motivation, Self-efficacy, and Risk Attitudes Among Entrepreneurs During Transition to a Market Economy. Journal of Socio-Economics, 40, 124-131. http://doi.org/10.1016/j.socec.2011.01.011

UNDP. (2002). Arab Human Development Report. In Generations, C. O. F. F. (Ed.), United Nations Publications. New York, NY.

UNESCO. (2002). Adult Illiteracy Rates (2000-2005). Retrieved from http://www.unesco.org/doha/countries/saudi.htm

United Nations Development Programme Undp. (2003). Arab Human Development Report. New York: United Nations Publications.

United Nations Development Programme Undp. (2015). Arab Human Development Report. New York: United Nations Publications. http://dx.doi.org/10.1108/14691930410512905

Verheul, I., Van Stel, A. \& Thurik, R. (2006). Explaining Female and Male Entrepreneurship at the Country Level. Entrepreneurship \& Regional Development, $18, \quad$ 151-183. http://dx.doi.org/10.1080/08985620500532053

Wang, C., Wong, P. \& Lu, Q. (2002). Tertiary Education and Entrepreneurial Intentions. Technological Entrepreneurship, 55-82.

Wärneryd, K. E. (1988). The Psychology of Innovative Entrepreneurship. In: VAN RAAIJ, W.F., VAN Veldhoven, G. M, \& Wärneryd, K. E. (Ed.), Handbook of Economic Psychology. Dordrecht: Kluwer Academic. http://dx.doi.org/10.1007/978-94-015-7791-5_11

Wilson, F., Kickul, J., \& Marlino, D. (2007). Gender Entrepreneurial Self-efficacy, and Entrepreneurial Career Intentions: Implications for Entrepreneurship Education. Entrepreneurship Theory and Practice, 31, 387-406. http://dx.doi.org/10.1111/j.1540-6520.2007.00179.x 
Wilson, R. (1995). Economic development in the Middle East. London: Routledge.

Wilson, R. (2001). New Regionalism, and GCC Trade: New Directions. New York, Prentice Hall.

Woldie, A., \& Adersua, A. (2004). Female Entrepreneurs in a Transitional Economy: Businesswomen in Nigeria. http://dx.doi.org/10.1108/03068290410515439

World Bank (2003a). Gender and Development in the Middle East and North Africa. Women in the Public Sphere (World Bank). Washington.

World Bank. (2003). Gender Equality and the Millennium Development Goals Gender and Development Group, Washington, World Bank.

World Bank. (2003). Trade, Investment and Development in the Middle East and North Africa. World Bank. Washington.

\section{Copyrights}

Copyright for this article is retained by the author(s), with first publication rights granted to the journal.

This is an open-access article distributed under the terms and conditions of the Creative Commons Attribution license (http://creativecommons.org/licenses/by/4.0/). 